\title{
ANALISIS HUBUNGAN ANTARA COPING STRATEGI DENGAN TINGKAT PENDAPATAN PETANI KARET DI KECAMATAN MESTONG KABUPATEN MUARO JAMBI
}

\author{
Deny Oscar ${ }^{1)}$, Armen Mara $^{2)}$ dan Saidin Nainggolan ${ }^{2)}$ \\ 1) Alumni Program Studi Agribisnis Fakultas Pertanian Universitas Jambi \\ 2) Staf Pengajar Program Studi Agribisnis Fakultas Pertanian Universitas Jambi \\ Email :denioscar20@gmail.com
}

\begin{abstract}
ABSTRAK
Penelitian ini bertujuan: 1) untuk mengetahui tingkat pendapatan petani karet di Kecamatan Mestong Kabupaten Muaro Jambi, 2) untuk mengetahui hubungan antara tingkat pendapatan petani karet dengan "coping strategy" petani karet di Kecamatan Mestong Kabupaten Muaro Jambi. Penelitian dilakukan di Desa Suka Maju, Desa Muaro Sebapo dan Desa Nyogan Kecamatan Mestong Kabupaten Muaro Jambi. Penarikan sampel dilakukan dengan dua tahap, tahap pertama dilakukan metode pengambilan contoh kelompok distratifikasi (Stratified Cluster Sampling), tahap kedua yaitu penarikan sampel dilakukan dengan cara Non Probability Sampling dengan jumlah sampel sebanyak 44 orang. Dari hasil penelitian dapat ditarik kesimpulan bahwa,1) Harga karet mengalami fluktuatif, harga karet tertinggi terdapat pada tahun 2011 yaitu pada tingkat harga $\mathrm{Rp} 17.025 / \mathrm{Kg}$, sedangkan harga terendah terdapat pada tahun 2015 yaitu pada tingkat harga Rp 4.500/Kg. Perbedaan nilai harga tertinggi dan harga terendah adalah sebesar $\mathrm{Rp}$ 12.525 atau mencapai $333,3 \%$. 2) Terdapat perbedaan pendapatan petani karet di daerah penelitian dengan yang diharapkan, besarnya pendapatan tidak mencukupi kebutuhan sehingga perlu melakukan strategi untuk dapat beradaptasi pada tekanan ekonomi guna memenuhi kebutuhan 3)Terdapat hubungan yang nyata antara tingkat pendapatan petani dengan "coping strategy" yang dilakukan petani dalam mengatasi fluktuasi harga karet di Kecamatan Mestong Kabupaten Muaro Jambi, dimana petani yang berpendapatan rendah cenderung melakukan strategi aktif dan sebaliknya untuk petani berpendapatan tinggi.
\end{abstract}

\section{Kata Kunci: Strategi, Keaktifan, Pendapatan}

\section{ABSTRACT}

This research aims to: 1) to know the income level of rubber farmer in Mestong Sub-district of Muaro Jambi Regency; 2) to know the correlation between income level of rubber farmer with coping strategy In Mestong District Muaro Jambi Regency. The research was conducted in Suka Maju Village, Muaro Sebapo Village and Nyogan Village, Mestong District Muaro Jambi Regency. The sampling was conducted in two stages, the first stage is the stratified sampling method (Stratified Cluster Sampling), the second stage is the sampling is done by Non Probability Sampling with a total sample of 44 people. From the research results can be concluded that, 1) Rubber prices fluctuate, the highest price of rubber is in 2011 at the price level $\mathrm{Rp} 17.025 / \mathrm{Kg}$, while the lowest price is in 2015 at the price of $\mathrm{Rp} \mathrm{4,500/} \mathrm{Kg.} \mathrm{The} \mathrm{difference} \mathrm{between} \mathrm{the} \mathrm{highest} \mathrm{and} \mathrm{lowest} \mathrm{price}$ is $\mathrm{Rp} 12,525$ or $333.3 \%$. 2) There is a difference of income of rubber farmers in the research area with the expected, the amount of income is not sufficient so that need to do strategy to adapt to the economic pressure to meet the needs 3 ) There is a real relationship between the income level of farmers with "coping strategy" In overcoming the dynamics of rubber prices in Mestong Subdistrict of Muaro Jambi Regency, where low-income farmers tend to do active.

Keyword:Strategy, liveliness, Income 


\section{PENDAHULUAN}

Subsektor perkebunan merupakan subsektor yang berperan penting dalam pembangunan khususnya di bidang pertanian, karena sebagai penyedia lapangan pekerjaan dan penyedia bahan baku untuk industri dan penghasil devisa. Peranan subsektor perkebunan tidak diragukan lagi dalam perekonomian, pembangunan subsektor perkebunan diarahkan pada peningkatan produksi untuk memenuhi kebutuhan industri, meningkatkan ekspor, memperluas lapangan pekerjaan dan mendorong kesempatan berusaha khususnya untuk meningkatkan pendapatan petani (BPS Pusat, 2014).

Sektor pertanian memiliki peranan penting dalam perekonomian di Provinsi Jambi salah satunya pada subsektor perkebunan, sebagai sumber pendapatan dan lapangan pekerjaan bagi masayarakat. Sektor pertanian merupakan sektor yang mendominasi perekonomian di Provinsi Jambi hingga saat ini. Hal ini di tunjukkan oleh kontribusi sektor pertanian terhadap PDRB Provinsi Jambi pada tahun 2014 sebesar 27,81 persen (BPS Pusat, 2014).

Kebutuhan karet akan terus meningkat seiring meningkatnya kebutuhan manusia terhadap barang-barang yang terbuat dari bahan elastis. Karet adalah polimer hidrokarbon yang terbentuk dari (latex) yang diperoleh dari getah beberapa jenis pohon. Melukai kulit pohon karet akan memberikan respons yang menghasilkan latex. Lahan perkebunan karet terluas di dunia dimiliki Indonesia, sebagian besar berada di wilayah Sumatra dan Kalimantan. Namun dari segi produktivitas masih jauh di bawah Thailand dan Malaysia (BPS Pusat, 2014).

Karet (Havea brasilansis) sebagai salah satu komoditi yang mempengaruhi perekonomian di Provinsi Jambi karena sebagian besar penduduk di daerah Jambi bermata pencaharian di bidang perkebunan karet baik itu sebagai petani, buruh tani, pedagang dan jasa penunjang pengolahan di pabrik. Sektor perkebunan merupakan salah satu sektor yang mempunyai peranan penting dalam meningkatkan pendapatan. Menurut data Dinas Perkebunan Provinsi Jambi tahun 2015, tanaman karet merupakan salah satu komoditi yang memiliki arti ekonomi dan sosial bagi masyarakat di Provinsi Jambi. Hal ini bisa di lihat dari perkembangan luas areal tanaman karet dan produksinya di Provinsi Jambi. Meskipun luas areal perkebunan karet meningkat setiap tahunnya akan tetapi jumlah produksi karet mengalami penurunan pada tahun 2014 (Disbun Provinsi Jambi, 2014).

Provinsi Jambi merupakan salah satu sentra produksi karet nasional. Karet alam telah sejak lama menjadi komoditi trade mark dari Provinsi Jambi.Salah satu kabupaten di Provinsi Jambi yang mengusahakan karet adalah kabupaten Muaro Jambi. Pada tahun 2013 Kabupaten Muaro Jambi merupakan kabupaten dengan produktivitas karet tertinggi yaitu sebesar $1.009 \mathrm{~kg} / \mathrm{ha} /$ tahunnamun pada tahun 2014 produktivitas karet di Kebupaten Muaro Jambi turun menjadi $996 \mathrm{~kg} / \mathrm{ha} /$ tahundengan luas areal sebesar 55.898 Ha dan produksi sebanyak 31.603 ton yang menyerap tenaga kerja dengan jumlah petani sebanyak 15.190 KK (Dinas Perkebunan Provinsi Jambi, 2014).

Disamping penurunan produktivitas dalam usahatani karet yang menyebabkan pendapatan menurun, perkembangan kebutuhan hidup manusia yang terdiri dari kebutuhan primer, sekunder dan tersier dapat ditentukan oleh pendapatan. Dengan kondisi rendahnya harga karet akan mempengaruhi pendapatan petani yang nantinya akan memberikan dampak yang mengakibatkan turunnya pendapatan petani, turunnya daya beli petani, turunnya kemampuan investasi petani serta pengalihan sumber penghasilan petani ke sumber penghasilan selain usahatani karet. 
Tabel 2. Harga rata-rata bahan olah karet di Kabupaten Muaro Jambi tahun 2008-2014

\begin{tabular}{cc}
\hline Tahun & Harga Karet (Rp) \\
\hline 2008 & 10.491 \\
2009 & 8.717 \\
2010 & 13.467 \\
2011 & 17.025 \\
2012 & 12.558 \\
2013 & 8.840 \\
2014 & 7.788 \\
\hline
\end{tabular}

Sumber: Dinas Perkebunan Provinsi Jambi 2008-2014

Berdasarkan latar belakang dan permasalahan yang dikemukakan, maka penelitian ini bertujuan untuk 1) mendeskripsikan dinamika harga karet di Kecamatan Mestong Kabupaten Muaro Jambi, 2) menganalisis besarnya pendapatan petani karet di Kecamatan Mestong Kabupaten Muaro Jambi, 3) menganalisis hubungan antara tingkat pendapatan petani dengan coping strategy petani karet di Kecamatan Mestong Kabupaten Muaro Jambi.

\section{METODE PENELITIAN}

Penelitian ini dilakukan di Desa Suka Maju, Desa Muaro Sebapodan Desa NyoganKecamatan Mestong Kabupaten Muaro Jambi secara sengaja (purposive), dengan pertimbangan bahwa desa tersebut sebagian besar penduduknya menggantungkan hidupnya pada perkebunan karet yang dihasilkan. Objek dalam penelitian ini adalah petani pemilik sekaligus penyakap berjumlah 1685 petani. Besarnya sampel disetiap desa ditentukan secara proporsional dengan menggunakan formula (Nazir, 1998). Hal ini dapat dilihat pada Tabel 1.

Tabel 1. Nama Desa Sampel, Jumlah Populasi dan Jumlah Sampel di Kecamatan Mestong Kabupaten Muaro Jambi 2017

\begin{tabular}{clcc}
\hline No. & \multicolumn{1}{c}{ Desa } & Populasi & Sampel \\
\hline 1 & Suka Maju & 634 & 16 \\
2 & Muaro Sebapo & 335 & 9 \\
3 & Nyogan & 716 & 19 \\
\hline \multicolumn{2}{c}{ Total } & $\mathbf{1 6 4}$ & $\mathbf{4 4}$ \\
\hline
\end{tabular}

Jumlah sampel sebanyak 44 orang dan penentuan sampel dilakukan secara acak (Random Sampling).Penelitian ini dilaksanakan dari tanggal 17 Desember 2016 sampai 17 Januari 2017. Metode analisis data yang digunakan untuk mengetahui dinamikaharga karet adalah analisis deskriptif. Selanjutnya analisis yang digunakan untuk menjawab tujuan dua menggunakan analisispendapatan.Untuk menjawab tujuan tiga digunakananalisis statistik non parametrik yaitu Chi-Square sebagai berikut:

$$
\chi^{2}=\Sigma \frac{f o-f e)^{2}}{f e}
$$

Dalam penyajiannya nilai $\chi^{2}$ hitung dibandingkan dengan $\chi^{2}$ tabel dengan ketentuan sebagai berikut:

Jika $\chi^{2}{ }_{\text {hit }}\left\{\leq \chi_{\text {tab }}^{2}\left(\alpha=5 \%, \mathrm{db}=(\mathrm{b}-1)(\mathrm{k}-1)=2\right.\right.$ terima $\left.\mathrm{H}_{0}\right\}$ 
Jika $\chi_{\text {hitt }}^{2}\left\{>\chi^{2}{ }_{\text {tab }}\left(\alpha=5 \%, \mathrm{db}=(\mathrm{b}-1)(\mathrm{k}-1)=2\right.\right.$ terima $\left.\mathrm{H}_{1}\right\}$

Dimana :

$\mathrm{H}_{0}$ : Tidak terdapat pengaruh tingkat pendapatan petani terhadap "coping strategy" petani karet di Kecamatan Mestong Kabupaten Muaro Jambi.

$\mathrm{H}_{1}$ : Terdapat pengaruh tingkat pendapatan petani terhadap "coping strategy" petani karet di Kecamatan Mestong Kabupaten Muaro Jambi.

\section{HASIL DAN PEMBAHASAN}

\section{Identitas Petani Responden}

Petani responden dalam penelitian ini adalah petani karet di Desa Suka Maju, Desa Muaro Sebapo dan Desa Nyogan Kecamatan Mestong Kabupaten Muaro Jambi. adapun yang menjadi penentu identitas petani sampel di daerah penelitian mencakup umur petani, tingkat pendidikan, pengalaman berusahatani, dan jumlah anggota keluarga. Dapat dilihat pada Tabel 2.

Tabel 2. Identitas Petani Sampel Berdasarkan Umur Petani, Tingkat Pendidikan, Pengalaman Berusahatani, Dan Jumlah Anggota Keluarga Di Daerah Penelitian Tahun 2016

\begin{tabular}{clclcc}
\hline No. & Identitas Petani Sampel & Kategori & Standar Ukuran & N & Persentase (\%) \\
\hline 1 & Umur Petani & Produktif & $<55$ thn & 54 & 87,10 \\
& & Tidak Produktif & $>55$ thn & 8 & 12,90 \\
2 & Tingkat Pendidikan & Tinggi & $>$ SMP & 14 & 22,58 \\
& & Rendah & $<$ SMP & 48 & 77,42 \\
3 & Pengalaman & Tinggi & $>20$ thn & 9 & 14,52 \\
& Berusahatani & Rendah & $<20$ thn & 53 & 85,48 \\
4 & Jumlah Anggota Keluarga & Besar & $>4$ orang & 32 & 51,61 \\
& & Kecil & $<4$ orang & 30 & 48,39 \\
\hline
\end{tabular}

Tabel 2 menunjukkan bahwa rata-rata umur petani sampel berada pada rentan usia $<55$ tahun (usia produktif). Umur petani sampel merupakan peranan penting dalam usahatani karena hal ini mempengaruhi kemampuan dan kecepatan berfikir dan mengambil keputusan. Hal ini sesuai dengan pendapatan Hernanto (1991), usia produktif dalam berusahatani yaitu usia 15-55 tahun. Menurut Hernanto (1996), tingkat pendidikan petani mempengaruhi cara berpikir, menerima, dan menata hal-hal baru. Semakin baik tingkat pendidikan, akan mempengaruhi adopsi teknologi dan keterampilan manajemen dalam mengelola usahatani sayuran. Dari Tabel 2 di atas, persentase terbesar terdapat pada tingkat pendidikan < SMP sebanyak 48 orang atau 77,42\%. Menurut Hernanto (1996), bahwa jumlah anggota keluarga akan berpengaruh dalam kegiatan usahatani. Petani yang memiliki anggota keluarga yang akan memakainya untuk kegiatan usahatani sehingga tidak perlu menggunakan tenaga kerja luar keluarga. Dilihat dari Tabel di atas, jumlah anggota keluarga terbesar dalam petani sampel adalah $>4$ orang atau 51,61 \%.

\section{Pola Usaha Petani Karet}

Pola tanam ini dikelompokkan berdasarkan jenis sayuran yang ditanami oleh petani dalam satu lahan yang sama selama satu tahun. Berikut gambaran mengenai distribusi sayuran berdasarkan pola tanam di daerah penelitian dapat dilihat pada Tabel 3 berikut ini:

Tabel 3. Distribusi Petani Karet Berdasarkan Pola UsahaSecara Umum Di Daerah Penelitian Tahun 2017 


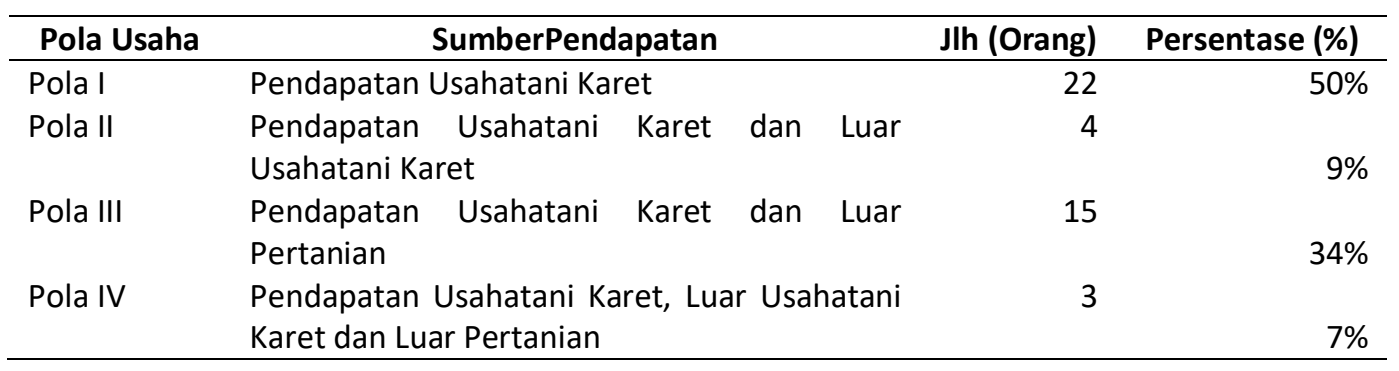

Tabel 3 menunjukkan bahwa petani di daerah penelitian melaksanakan 4 pola usaha yang berbeda-beda. Banyaknya pola usaha yang digunakan petani di daerah penelitian adalah pola usaha I sebanyak 22 petani sampel sebanyak 22 orang atau $50 \%$. Kemudian pola usaha III dengan jenis pendapatan usahatani karet dan luar pertanian berjumlah 15 orang atau $34 \%$ dari total petani.

\section{Dinamika Harga Karet}

Informasi tentang perubahan harga sangat penting diketahui oleh petani agar harga yang diberlakukan oleh pedagang tidak semaunya saja sehingga dapat merugikan petani. Sebagian besar petani tidak mengetahui perubahan harga, sehingga petani menerima berapapun harga yang diberlakukan oleh pedagang. Disamping itu ada keengganan pedagang untuk menginformasikan terhadap perubahan kenaikan harga, sedangkan sebaliknya terhadap penurunan harga akan cepat di informasikan kepada petani, hal ini tentunya akan merugikan petani.

Beberapa faktor yang dapat mempengaruhi tingkat harga bokar adalah desakan ekonomi produsen, keadaan cuaca atau iklim, kadar basi,kadar kering, keadaan waktu, tempat, timbangan yang masih panas terutama menggunakan timbangan gantung, penetapan harga yang tidak transparan, biaya transportasi yang tidak jelas. Hal ini disampaikan oleh salah seorang petani bokar di Kecamatan Mestong.

Fluktuasi harga karet memiliki pengaruh yang besar terhadap petani. Petani memerlukan kepastian harga untuk memutuskan strategi apa yang mereka lakukan untuk mengurangi resiko akibat turunnya harga dan petani juga perlu mengetahui harga karet untuk mengendalikan pengeluaran. Oleh karena itu, petani perlu mengetahui pola data harga untuk mengurangi resiko akibat ketidakpastian harga. Harga rata-rata bhan olah karet di daerah penelitian dapat dilihat pada tabel 4 berikut:

Tabel 4. Harga rata-rata bahan olah karet di Kabupaten Muaro Jambi tahun 2008-2014

\begin{tabular}{cc}
\hline Tahun & Harga Karet (Rp) \\
\hline 2008 & 10.491 \\
2009 & 8.717 \\
2010 & 13.467 \\
2011 & 17.025 \\
2012 & 12.558 \\
2013 & 8.840 \\
2014 & 7.788 \\
2015 & 4.500 \\
\hline
\end{tabular}

Sumber: Dinas Perkebunan Provinsi Jambi 2008-2015

Tabel 4 menunjukkan bahwa harga karet tertinggi berdasarkan data tahunan terdapat pada tahun 2011 yaitu pada tingkat harga $\mathrm{Rp} 17.025 / \mathrm{Kg}$, sedangkan harga terendah terdapat pada tahun 2015 yaitu pada tingkat harga Rp 4.500/Kg. Perbedaan nilai harga tertinggi dan harga terendah adalah sebesar Rp 12.525. Nilai tersebut dirasa sangat tinggi dimana perbandingan antara harga tertinggi dengan harga terendah yang mencapai 
$333,3 \%$ tentunya akan dapat menimbulkan kerugian bagi pihak-pihak yang berkepentingan terhadap komoditas karet ini khususnya bagi petani karet yang menggantungkan hidupnya pada komoditi ini. Hal ini sejalan menurut Nancy, et al(2014) yang menyatakan bahwa rendahnya harga karet telah merugikan petani yang memberikan dampak turunnya pendapatan petani perbulan, turunnya kemampuan investasi petani dalam membangun kebun karet unggul dan turunnya daya beli petani.

\section{Peneriman, Biaya dan Pendapatan Usahatani Karet}

Penerimaan usahatani karet dalam penelitian ini adalah jumlah produksi yang dihasilkan petani karet dalam satu tahun dengan harga jual produksi karet.Analisa biaya yang dilakukan dalamusahatani karet adalah seluruh biaya yang dikeluarkan selama satu tahun.Biaya tetap merupakan biaya yang dikeluarkan yang jumlahnya tidak habis dalam satu kali proses produksi atau biaya yang tidak bergantung pada produksi yang dihasilkan.Biaya variabel merupakan biaya yang dikeluarkan yang jumlahnya bergantung pada produksi yang dihasilkan atau biaya yang habis dalam satu kali pakai.Adapun perhitungan biaya meliputi biaya tetap dan biaya variabel.Pendapatan yang dimaksud adalah pendapatan yang diterima dari jumlah produksi yang dihasilkan dengan harga produk yang bersangkutan yang kemudian dikurangi oleh biaya produksi.Rata-rata penerimaan, biaya dan pendapatan usahatani sayuran dapat dilihat pada Tabel 5-13 berikut:

Tabel 5. Rata-Rata Penerimaan, Biaya Dan Pendapatan Usahatani karet Di Daerah Penelitian Untuk Satu Kali Proses Produksi Tahun 2016

\begin{tabular}{clr}
\hline No. & Uraian & Nilai (Rp/Ha/MT) \\
\hline 1 & Penerimaan & $\mathbf{1 6 . 7 7 6 . 5 3 8}$ \\
2 & Biaya Total (Total Cost) & $\mathbf{2 0 6 7 . 4 5 4}$ \\
3 & Pendapatan & $\mathbf{1 4 . 7 0 9 . 0 8 4}$ \\
\hline 4 & Keuntungan & $\mathbf{1 4 . 7 0 9 . 0 8 4}$ \\
\hline
\end{tabular}

Tabel 5 menunjukkan bahwapenerimaan usahatani karet untuk satu kali proses produksi sebesar Rp. 16.776.538/Ha/MT dari total penerimaan usahatani sayuran keseluruhan.Pendapatan usahatani sawi sebesar Rp. 14.709.084/Ha/MTdari total pendapatan usahatani karet, total biaya keseluruhan sebesar Rp. 2.067.454/Ha/MT dari total biaya produksi yang digunakan. Keuntungan dalam usahatani sawi sebesar Rp. 14.709.084/Ha/MT dari total keuntungan usahatani karet di daerah penelitian.

\section{Strategi Aktif}

Strategi aktif adalah suatu bentuk strategi yang mengoptimalkan segala potensi keluarga untuk peningkatan penghasilan karena tuntutan hidup yang semakin besar. Berbagai bentuk strategi yang dibangun oleh keluarga petani karet antara lain: melakukan aktifitas sendiri atau melakukan pembagian kerja keluarga, mencari kerja sampingan, dan memanfaatkan potensi hutan untuk menambah pendapatan.

Sistem strategi aktif yang dilakukan oleh petani karet di Kecamatan Mestong ternyata mampu membuat mereka untuk tetap dapat beradaptasi dengan lingkungan sekitarnya. Sehingga sistem adaptasi dapatlah disebut sebagai sebuah strategi aktif manusia. Adaptasi dapat dilihat sebagai usaha untuk memelihara kondisi kehidupan dalam menghadapi perubahan.

Pada penelitian ini menunjukkan tentang situasi harga bahan olah karet yang mengalami penurunan, sehingga memaksa keluarga petani karet khususnya di Kecamatan Mestong Kabupaten Muaro Jambi untuk berpikir tentang strategi apa yang harus mereka 
lakukan supaya bisa bertahan hidup, dan memenuhi kebutuhan-kebutuhan keluarganya dengan pendapatan yang tidak menentu.

Dari hasil penelitian diketahui bahwa sebanyak 26 dari 44 petani responden melakukan strategi aktif. Beberapa strategi aktif atau jenis pekerjaan sampingan yang dilakukan petani di daerah penelitian pada saat terjadi penurunan harga karet.Strategi aktif petani di daerah penelitian dapat dilihat pada Tabel 6 .

Tabel 6. Distribusi petani berdasarkan strategi aktif di daerah penelitian tahun 2016

\begin{tabular}{lcc}
\hline \multicolumn{1}{c}{ Strategi Aktif } & \multicolumn{2}{c}{ Jumlah Petani } \\
\cline { 2 - 3 } & KK & Persentase (\%) \\
\hline Beternak Ayam & 3 & 11 \\
Beternak Bebek & 1 & 4 \\
Beternak Kambing & 1 & 4 \\
Bertani Sayur & 1 & 4 \\
Tukang Cukur & 1 & 4 \\
Honorer & 1 & 4 \\
Pedagang Kelontong & 4 & 15 \\
Buruh Bangunan & 6 & 23 \\
Gitaris & 1 & 4 \\
Penjahit & 1 & 4 \\
Bengkel & 2 & 8 \\
Gesek Kayu & 3 & 11 \\
Tukang Urut & 1 & 4 \\
\hline Jumlah & 26 & 100 \\
\hline
\end{tabular}

Tabel 6 menunjukkan bahwa distribusi strategi aktif petani yang dilakukan petani di daerah penelitian. Dari tabel tersebut dilihat bahwa persentase terbesar pada petani yang melakukan strategi aktif yaitu 6 KK dari 26 KK sebagai pedagang kelontong yaitu sebanyak $23 \%$. Dengan demikian dapat disimpulkan bahwa, beberapa strategi aktif dilakukan petani merupakan suatu pengetahuan atau keahlian yang mereka miliki sehingga mereka memanfaatkan pengetahuan atau keahlian itu untuk menambah penghasilan mereka.Beberapa pekerjaan yang memerlukan keahlian atau pengetahuan seperti: Tukang cukur, Gitaris, Penjahit, Bengkel, Gesek kayu dan Tukang urut.

\section{Strategi Pasif}

Strategi pasif yang dilakukan petani di Kecamatan Mestong merupakan suatu model penekanan terhadap pola subsistensi dengan cara mengedepankan kebutuhan konsumsi daripada kebutuhan-kebutuhan sosial ekonomis. Penekanan atau pengetatan pengeluaran merupakan strategi yang bersifat pasif, yaitu mengurangi pengeluaran keluarga (misalnya pengeluaran biaya untuk sandang, pangan, biaya sosial, transportasi, kesehatan, pendidikan, dan kebutuhan sehari-hari lainnya). Berdasarkan hasil penelitian ini menunjukkan bahwa mereka sering menekan biaya pengeluaran dan menghindari resiko.

Petani karet di Kecamatan Mestong selain melakukan strategi aktif, mereka juga melakukan strategi pasif yaitu menghemat pengeluaran dengan mengurangi konsumsi daging, mengurangi rekreasi, mengurangi ke Salon, dan mengurangi membeli pakaian. Dari hasil penelitian diketahui bahwa sebanyak 11 dari 44 petani responden melakukan 
strategi pasif. Kegiatan ini dilakukan sebagai upaya untuk menghemat pengeluaran keluarga.Strategi pasif petani di daerah penelitian dapat dilihat pada Tabel 7.

Tabel 7. Strategi yang dilakukan petani pasif di daerah penelitian tahun 2016

\begin{tabular}{lcc}
\hline \multirow{2}{*}{ Strategi Pasif } & \multicolumn{2}{c}{ Jumlah Petani } \\
\cline { 2 - 3 } & KK & Persentase (\%) \\
\hline Mengurangi Konsumsi Daging & 6 & 55 \\
Mengurangi Rekreasi & 1 & 9 \\
Mengurangi ke Salon & 1 & 9 \\
Mengurangi Membeli Pakaian & 3 & 27 \\
\hline \multicolumn{1}{c}{ Jumlah } & $\mathbf{1 1}$ & $\mathbf{1 0 0}$ \\
\hline
\end{tabular}

Tabel 24 mempelihatkan ada beberapa pilihan strategi yang dilakukan petani pasif di daerah penelitian, yaitu mengurangi konsumsi daging, mengurangi rekreasi, dan mengurangi ke salon. Dari tabel tersebut dapat dilihat bahwa persentase terbesar adalah mengurangi konsumsi daging ada sebanyak $55 \%$, mengurangi rekreasi $9 \%$, mengurangi ke salon $9 \%$, dan mengurangi membeli pakaian $27 \%$. Dengan demikian dapat disimpulkan bahwa mengurangi konsumsi daging yang telah dilakukan oleh petani karet di Kecamatan Mestong merupakan kegiatan ekonomis untuk mengurangi anggaran konsumsi keluarga. Hasil dari strategi pasif tersebut cukup untuk menekan pengeluaran pokok atau konsumsi keluarga, meskipun tidak terlalu besar, akan tetapi sangat mempengaruhi bagi kehidupan mereka.

\section{Strategi Jaringan}

Dampak penurunan harga karet terhadap perekonomian masyarakat petani karet di Kecamatan Mestong Kabupaten Muaro Jambi memang sangat mempengaruhi kondisi ekonomi keluarga mereka, dan apabila krisis tersebut terus berlanjut maka dapat mengancam keberlangsungan hidup mereka. Dalam hal ini di samping melakukan strategi aktif dan strategi pasif, masyarakat petani karet di Kecamatan Mestong juga memanfaatkan kekerabatan sebagai jaringan untuk meminjam uang ketika kebutuhankebutuhan ekonomi telah mendesak sedangkan keuangan tidak lagi mencukupi untuk memenuhi kebutuhan-kebutuhan keluarganya.

Meminjam uang merupakan salah satu yang dilakukan oleh masyararakat petani karet di Kecamatan Mestong ketika terjadi desakan ekonomi seperti, berkurangnya pendapatan masyarakat petani akibat turunnya harga karet sehingga tidak mencukupi lagi untuk memenuhi kebutuhan sehari-hari. Untuk dapat memenuhi tuntutan itu mereka melakukan suatu usaha yaitu meminjam uang. Meminjam uang kepada tetangga tidak dilandasi dengan sistem bunga uang, akan tetapi hanya dengan modal kepercayaan. Sesama kerabat atau tetangga telah terbina rasa saling mempercayai satu sama lainnya dan hubungan yang bersifat timbal balik lebih berorientasi pada moral dan perasaan. Tidak ada sanksi atau pun jaminan yang bersifat dalam kegiatan ekonomis tersebut.

Berbeda halnya ketika petani meminjam uang kepada rentenir atau koperasi memang modal kepercayaan (trust) masih berlaku dalam hal ini. Akan tetapi rasa percaya yang terbentuk tidaklah seperti yang percaya yang terjalin dalam kehidupan kekerabatan. Dari hasil penelitian diketahui bahwa sebanyak 7 dari 44 petani responden melakukan strategi jaringan. Rasa percaya terhadap sesama kerabat lebih berorientasi kepada kekeluargaan dan perasaan persaudaraan, sedang kan trustyang terbentukdalam hubungan kepada Bank lebih berdasarkan azas keuntungan.Strategi jaringan petani di daerah penelitian dapat dilihat pada Tabel 8. 
Tabel 8. Distribusi petani berdasarkan strategi jaringan di daerah penelitian tahun 2016

\begin{tabular}{ccc}
\hline \multirow{2}{*}{ Strategi Jaringan } & \multicolumn{2}{c}{ Jumlah Petani } \\
\cline { 2 - 3 } & KK & Persentase (\%) \\
\hline Meminjam ke Kerabat & 5 & 71 \\
Meminjam uang ke Bank & 2 & 29 \\
\hline Jumlah & $\mathbf{7}$ & $\mathbf{1 0 0}$ \\
\hline
\end{tabular}

Tabel 8 mempelihatkan distribusi strategi jaringan petani yang dilakukan petani di daerah penelitian. Dari tabel tersebut dilihat bahwa persentase terbesar pada petani yang melakukan strategi jaringan yaitu 5 KK dari 7 KK lebih memilih meminjam uang ke kerabat daripada ke Bank yaitu sebanyak $71 \%$.Dengan demikian dapat disimpulkan bahwa, hasil dari strategi jaringan meminjam uang ke kerabat mampu menekan masalah ekonomi yang dihadapi, dan dapat membuat mereka sampai saat ini masih bisa eksis walaupun dengan kehidupan yang seadanya.

\section{Hubungan Tingkat Pendapatan dengan "Coping Strategy" Petani Karet}

Tingkat pendapatan yang dimaksud dalam penelitian ini adalah seberapa besar pendapatan yang diterima petani dari usahatani karet, apabila tingkat pendapatan dari usahatani karet tergolong rendah apakah akan mempengaruhi pilihan petani dalam memilih "coping strategy" guna memenuhi kebutuhannya sehari-hari. Untuk mengetahui hubungan tingkat pendapatan dengan"coping strategy" petani dapat dilihat pada tabel 9.

Tabel 9. Model Uji Chi-Square Tingkat Pendapatan Petani Berhubngan dengan Strategi Petani “Coping Strategy"di Daerah Penelitian, Tahun 2016

\begin{tabular}{ccccc}
\hline Strategi Petani Karet & \multicolumn{2}{c}{ Tingkat Pendapatan } & \multirow{2}{*}{ Jumlah } \\
\cline { 2 - 4 } & Tinggi & Rendah & 23 \\
Aktif & 14 & 9 & 21 \\
\hline Jusif & 8 & 13 & 44 \\
\hline
\end{tabular}

Tabel 9 menunjukkan bahwa semakin rendah pendapatan petani maka strategi yang dilakukan petani semakin aktif dan sebaliknya. Hal ini menunjukkan bahwa tingkat pendapatan petani di daerah penelitian masih rendah yaitu berjumlah 31 orang petani sampel dan strategi yang dominan mereka lakukan ketika pendapatan mereka rendah adalah strategi aktif yaitu berjumlah 26 orang petani sampel.Strategi aktif yaitu optimalisasi sumber daya manusia atau mengoptimalkan segala potensi keluarga untuk peningkatan penghasilan.

Berdasarkan hasil uji statistik nonparametricdengan menggunakan Uji Chi-Square $\left(x^{2}\right)$ diperoleh nilai $x^{2}{ }_{h i t}$ sebesar 4,14 dan $x^{2}$ tab sebesar 3,841 maka nilai $x^{2}{ }_{h i t}$ lebih besar dari $x^{2}$ tab, dengan demikian dapat disimpulkan bahwa terdapat hubungan antara tingkat pendapatan dengan strategi petani karet di Kecamatan Mestong Kabupaten Muaro Jambi, sehingga dari kesimpulan tersebut dapat diputuskan tolak Ho terima Ha. Hal ini sejalan dengan penilitian yang dilakukanSiregar (2009), penununan harga karet yang terjadi sangat signifikan menyebabkan pendapatan petani berkurang sehingga mereka melakukan berbagai cara atau strategi agar dapat memenuhi kebutuhan hidupnya.

\section{KESIMPULAN}

Dari hasil penelitian dapat ditarik kesimpulan bahwa besarnya pendapatan tidak mencukupi kebutuhan sehingga perlu melakukan strategi untuk dapat berdaptasi pada 
tekanan ekonomi guna mencukupi kebutuhan mereka, Kemudian terdapat hubungan yang nyata antara tingkat pendapatan petani dengan "coping strategy" yang dilakukan petani dalam mengatasi dinamika harga. Artinya petani yang berpendapatan rendah cenderung melakukan strategi aktif.

\section{DAFTAR PUSTAKA}

BPS Pusat. 2014. Statistik Karet Indonesia. BPS, Jakarta.

Disbun Provinsi Jambi. 2014. Laporan Tahunan Disbun Provinsi Jambi, Jambi.

Siregar, E. I., 2009. Strategi Adaptasi Petani Rakyat Dalam Mensiasati Fluktuasi Harga Kelapa Sawit Sawit (Studi Kasus: Petani Kelapa Sawit Rakyat di Desa Tanjung Kecamatan Kampung Rakyat Kabupaten Labuhan Batu Selatan). Skripsi. Universitas Sumatera Utara, Medan.

Hernanto, Fadholi. 1991. IImu Usahatani. PT. Penebar Swadaya. Jakarta. . 1996. Ilmu Usahatani. PT. Penebar Swadaya. Jakarta. . 1998. Ilmu Usahatani. PT. Penebar Swadaya. Jakarta.

Nancy, C.,Syarifa, L. F.,Agustina, D. S., Supriadi, M. 2014. Dampak Rendahnya Harga Karet Terhadap Kondisi Sosial Ekonomi Petani Karet Di Sumatera Utara. Pusat penelitian karet. Sumatera Selatan, Palembang.

Nasir. 1998. Metode Penelitian. Ghalia Indonesia, Jakarta. 